\title{
PENGARUH ACTION LEARNING TERHADAP SIKAP REMAJA TENTANG HIV/AIDS
}

\author{
Muhammad Haris Zaelani*, Awaludin Jahid A**
}

\begin{abstract}
ABSTRAK
Angkakejadian HIV/AIDS di Indonesia dari tahun ketahun semakin meningkat. Menurut Komisi penanggulangan AIDS, sampai dengan bulan September 2007 penderita AIDS di Indonesia sekitar 1,3 juta dengan kematian 2.287 dan diperkirakan pada tahun 2020 akan mencapai 2,3 juta. Tujuan penelitian ini adalah untuk mengetahui pengaruh Action Learning terhadap sikap remaja tentang HIV/AIDS di SMK RISE Kedawung, Kabupaten Cirebon Tahun 2014. Metode yang digunakan dalam penelitian ini adalah Quasi Eksperimen dengan rancangan penelitian One Group Pretes-Posttest. Jumlah sampel sebanyak 91 responden, yang diambil secara Propotionate Stratified Random Sampling. Data diperoleh dengan cara wawancara melalui kuesioner dan data dianalisis secara statistik menggunakan uji Paired t-test. Dari hasil uji statistik di dapatkan bahwa Rata-rata (mean) skor sikap remaja tentang HIV/AIDS sebelum dilakukan intervensi Action Learning adalah 64,66 (tidak mendukung), rata-rata (mean) skor sikap remaja sesudah dilakukan intervensi Action Learning adalah 66,77 (mendukung), Ada pengaruh Action Learning terhadap sikap remaja tentang HIV/AIDS di SMK RISE Kedawung Kabupaten Cirebon ( $P$ Value sebesar 0,000).

Kata Kunci : : Action Learning, SikapRemaja
\end{abstract}

\begin{abstract}
The incidence of HIV / AIDS in Indonesia from year to year increase. According to the Commission on AIDS prevention, until the month of September 2007 AIDS patients in Indonesia around 1.3 million with 2,287 deaths in 2020 and is estimated to reach 2.3 million. The purpose of this study was to determine the effect of Action Learning on adolescent attitudes about HIV / AIDS in vocational RISE kedawung, Cirebon 2014. The method used in this study is Quasi-Experimentation with study design pretest-posttest One Group. The total sample of 91 respondents, which is taken through the formula propotionate Stratified Random Sampling. Data were obtained by interview questionnaires and analyzed statistically using Paired t-test. From the statistical test showed that the average (mean) score of teen attitudes about HIV / AIDS prior to the intervention of Action Learning is 64.66 (no support), the average (mean) score of teen attitudes before intervention Action Learning is 66, 77 (support), There is the influence of Action Learning on adolescent attitudes about HIV / AIDS in vocational RISE kedawung Cirebon (P Value $=0,000)$.
\end{abstract}

Keywords:Action Learning,Attitude Youth

\footnotetext{
* Alumni PSIK STIKes Cirebon Lulus Tahun 2014

** Staf Pengajar Program Studi DIII Keperawatan STIKes Cirebon
} 


\section{PENDAHULUAN}

Pada era globalisasi saat ini yang merupakan suatu bencana bagi manusia adalah timbulnya penyakit yang disebabkan oleh suatu penyakit menular yaitu HIV yang dapat menimbulkan AIDS. Acquired Immunodeficiency Syndrome (AIDS) adalah kumpulan dari gejala dan infeksi atau biasa disebut sindrom yang diakibatkan oleh kerusakan sistem kekebalan tubuh manusia karena virus HIV (Human Immunodeficiency Virus). ${ }^{1}$

Menurut (United Nation Development Program) penyebaran penyakit HIV/AIDS di dunia salah satunya di Amerika Serikat, diduga kuat terjadi melalui hubungan seksual, transfusi darah, dan pengguanaan jarum suntik bersama oleh pengguna narkoba. ${ }^{2}$

Angka kejadian HIV/AIDS di Indonesia dari tahun ke tahun semakin meningkat. Menurut Komisi penanggulangan AIDS, sampai dengan bulan September 2007 penderita AIDS di Indonesia sekitar 1,3 juta dengan kematian 2.287 dan diperkirakan pada tahun 2020 akan mencapai 2,3 juta. ${ }^{(5)}$ Direktur Jendral Pengendalian Penyakit dan Penyehatan Lingkungan (P2PL) Kementrian Kesehatan RI menyebutkan bahwa dimulai dari Januari hingga Maret 2011, jumlah pengidap AIDS baru yang dilaporkan mengalami peningkatan yakni menjadi 351 kasus dari 27 Kabupaten / Kota dari 12 Provinsi. Presentase kasus HIV/AIDS berdasarkan cara penularanya dibagi menjadi heteroseksual $(53,1 \%)$, disusul pengguna NAPZA suntik (penasun) $(37,9 \%)$, lelaki seks lelaki (LSL) $(3,0)$, perinatal atau dari ibu pengidap kepada bayinya $(2,6 \%) .^{3}$

Provinsi Jawa Barat menempati rangking kedua dalam kasus HIV/AIDS dengan angka 1.445 kasus AIDS, 1.174 kasus AIDS dengan Drug User dan 288 orang telah meninggal. Tingginya jumlah penderita HIV/AIDS di Jawa Barat sangat dipengaruhi oleh dua hal yaitu meningkatnya pengguna narkoba dengan jarum suntik serta maraknya seks bebas. ${ }^{4}$

Berdasarkan Kepala (P2PM) Pencegahan dan Pemberantasan Penyakit Menular Dinas Kesehatan Kabupaten Cirebon, prevalensi HIV/AIDS dari bulan Januari sampai dengan Oktober 2014 adalah sebanyak 935 orang yang terinfeksi HIV/AIDS. Tingginya jumlah penderita HIV/AIDS di Kabupaten Cirebon disebabkan oleh meningkatnya seks bebas, dari jumlah tersebut yang meninggal sebanyak 25 orang, adapun jumlah remaja yang positif HIV pada tahun 2014 sebanyak 5 orang, penyebaran HIV di kalangan remaja paling banyak melalui hubungan seks.

Remaja merupakan kelompok yang rentan terhadap IMS (Infeksi Menular Seksual) dengan jumlah terbesar mengidap HIV/AIDS.Masa remaja sangat erat kaitanya dengan perkembangan psikis pada priode pubertas dan diiringi dengan perkembangan seksual dan emosional yang kemudian tercermin dalam sikap danperilaku. Kondisi ini menyababkan remaja menjadi rentan terhadap masalah perilaku beresiko dalam penularan HIV/AIDS. ${ }^{5}$ Adapun kelompok remaja yang beresiko terhadap dalam penularan HIV/AIDS yaitu remaja dengan usia 13-16 tahun atau biasa disebut masa remaja awal, dimana pada masa remaja awal ini sifat berfikirnya masih belum mencapai kematangan, emosinya masih labil, sehingga terkadang bersikap semaunya sendiri, pada masa inilah yang biasanya disebut dengan kenakalan remaja. ${ }^{6}$

Upaya pencegahan dilakukan melalui pendidikan dan penyuluhan kesehatan kepada masyarakat terutama ditunjukan pada populasi beresiko yang mudah menyebarkan penyakit.Penularan dan penyebaran HIV/AIDS sangat berhubungan dengan perilaku beresiko. Penyuluhan dengan metode pembelajaran Action Learning merupakan salah satu penerapan penanggulangan melalui perubahan sikap individu dalam menentukan suatu tindakan ke arah yang lebih baik. ${ }^{7}$

Action learning adalah belajar sekaligus bertindak memberi siswa kesempatan untuk mengalami penerapan topik dan isi materi yang dipelajari atau didiskusikan dalam kelas dalam situasi kehidupan sesungguhnya, dan salah satu metode pembelajaran yang memusatkan kegiatan belajar siswa dari pada aktivitas mengajar guru. ${ }^{8}$ 
SMK RISE Kedawung adalah SMK kesehatan dengan akreditasi A yang memiliki siswa sebanyak 385 siswa dengan rata-rata usia 15 tahun sampai 19 tahun. Berdasarkan hasil studi pendahuluan yang dilakukan di SMK RISE Kedawung, Kabupaten Cirebon pada tanggal 9 November 2014 dengan cara wawancara dari 10 siswa didapatkan sebanyak 7 orang menjawab mereka akan berhati-hati dengan orang yang terkena HIV/AIDS dan 3 orang lainya menjawab memberi dukungan dan semangat kepada teman yang terkena HIV/AIDS. Berdasarkan hasil dari penelitian di Universitas Jember 2013 menunjukan ada pengaruh Action Learning terhadap pengetahuan, dan sikap remaja tentang HIV AIDS dan klinik Voluntary Counseling and Testing (VCT) Di SMK Perikanan dan Kelautan Puger Kabupaten Jember.

Tujuan untuk mengetahui pengaruh Action Learning terhadap sikap remaja tentang HIV/AIDS di SMK RISE Kedawung, Kabupaten Cirebon tahun 2014

\section{METODE PENELITIAN}

Metode yang digunakan dalam penelitian ini adalah Quasi Eksperimen dengan rancangan penelitian One Group Pretes-Posttest.. Populasi dalam penelitian ini adalah siswa kelas X, XI, XII SMK RISE Kedawung Kabupaten Cirebon Tahun 2014 berjumlah 119 orang. Sampel yang didapat dari rumus pengambilan besar sampel sejumlah 91 orang diambil dengan cara Propotionate Stratified Random Sampling.

Berdasarkan katerangan diatas untuk menentukan populasi dan sampel terdapat dua kriteria yaitu :

1. Kriteria inklusi

1) Remaja yang sekolah di SMK RISE Kedawung Kabupaten Cirebon.

2) Remaja yang berusia 15-19 tahun.

3) Remaja yang bersedia menjadi responden.

2. Kriteria Ekslusi

1) Remaja atau siswa yang jarang masuk sekolah.

2) Remaja yang berusia $>19$ tahun.

3) Remaja yang tidak bersedia menjadi responden penelitian.

Instrumen penelitian menggunakan lembar kuesioner dengan cara menggunakan skala likert yang terdiri alternatif jawaban (SS, S, KS, TS) untuk pertanyaan tentang sikap remaja tentang HIV/AIDS, Sedangkan instrumen Action Learning menggunakan prosedur pelaksanaan Action Learning sedangkan metode pengumpulan data menggunakan angket. Analisa data terdiri dari analisis univariat dan analisis bivariat. Analisis univariat digunakan untuk mendeskripsikan karakteristik setiap variabel. Pada penelitian ini dilakukan uji beda untuk mengetahui pengaruh Action Learning terhadap sikap remaja tentang HIV/AIDS dengan tingkat kemaknaan atau kesalahan 5\% (0,05). Teknik pengujian hipotesis yang digunakan dalam penelitian ini adalah uji Paired T-test.

\section{HASIL PENELITIAN}

\section{Sikap Remaja Tentang HIV/AIDS Sebelum dilakukan Intervensi Action Learning.}

Tabel. 1 Distribusi Frekuensi Sikap Remaja Tentang HIV/AIDS Sebelum dilakukan Intervensi Action Learning.

\begin{tabular}{ccccccc}
\hline Variabel & N & Min & Max & Mean & Median & Kategori \\
\hline Sikap Pre-Test & 91 & 54 & 78 & 64,66 & 65,00 & $\begin{array}{c}\text { Tidak } \\
\text { mendukung }\end{array}$
\end{tabular}


Tabel 1 menunjukkan bahwa sikap responden sebelum dilakukan intervensi Action Learning mempunyai skor minimal 54 dan skor maksimal 78 serta skor median 65,00 dengan skor rata-rata 64,66. Sehingga masuk dalam kategori sikap yang tidak mendukung.

Sikap Remaja Tentang HIV/AIDS Setelah dilakukan Intervensi Action Learning.

Tabel. 2 Distribusi Frekuensi Sikap Remaja Tentang HIV/AIDS Setelah dilakukan Intervensi Action Learning.

\begin{tabular}{ccccccl}
\hline Variabel & N & Min & Max & Mean & Median & Kategori \\
& & & & & & \\
\hline Sikap Post-Test & 91 & 54 & 79 & 66,77 & 67,00 & Mendukung
\end{tabular}

Tabel 2 menunjukkan sikap responden setelah dilakukan intervensi Action Learning mempunyai skor minimal 54 dan skor maksimal 79 serta skor median 67,00 dengan skor ratarata 66,77. Sehingga masuk dalam kategori sikap yang mendukung.

\section{Pengaruh Action Learning terhadap Sikap Remaja tentang HIV/AIDS}

Tabel 3 Hasil Uji Statistik Pengaruh Action Learning Terhadap Sikap Remaja Tentang HIV/AIDS di SMK RISE Kedawung Kabupaten Cirebon Tahun 2014.

\begin{tabular}{ccccccc}
\hline Variabel & N & Mean & SE & T & P value & SD \\
\hline Pre Test dan Post Test & 91 & 2,110 & 0,466 & $-4,525$ & 0,000 & 4,448 \\
& & & & & & \\
\hline
\end{tabular}

Tabel 3 menunjukkan bahwa berdasarkan hasil uji statistik didapatkan $P$ value sebesar 0.000 dimana kurang dari batas kritis penelitian 0,05 sehingga keputusan hipotesis adalah $\mathrm{Ha}$ diterima atau ada perbedaan yang bermakna antara kelompok pre-tes dan post-tes, sehingga dapat ditarik kesimpulan ada pengaruh Action Learning terhadap sikap remaja tentang HIV/AIDS di SMK RISE Kedawung Kabupaten Cirebon Tahun 2014.

\section{PEMBAHASAN}

\section{Sikap Remaja Tentang HIV/AIDS Sebelum Dilakukan Intervensi Action Learning.}

Pada penelitian ini, sikap remaja tentang HIV/AIDS sikapnya masih dikatakan tidak mendukung, karena sikap responden terhadap HIV/AIDS dapat dipengaruhi oleh beberapa faktor. Faktor yang mempengaruhi sikap salah satunya adalah pengetahuan, dimana ketika seseorang yang mempunyai pengetahuan yang kurang maka ia akan memiliki sikap yang kurang pula.

Dilapangan peneliti menemukan bahwa sebagian responden mengetahui tentang HIV/AIDS namun belum mengaplikasikannya ke dalam keseharian. Ini berarti pengetahuan responden hanya ditingkat "tahu" belum ditingkat aplikasi.

Faktor emosi responden juga mempengaruhi sikap. Sikap remaja yang cenderung bersikap pemurung. sering marah-marah dan berprilaku kasar, egoistis dan tidak toleran, bersikap lebih kritis, suka memberontak ingin selalu diperhatikan, sering melamun memikirkan masa depanya.

Hal ini sesuai dengan teori menurut Notoatmodjo yang membagi tingkat pengetahuan kognitif kedalam 6 tingkatan yaitu tahu, memahami, aplikasi, analisis, sintesis dan evaluasi. Dimana, tahu diartikan sebagai mengingat kembali (recall) terhadap sesuatu yang spesifik dari seluruh bahan yang dipelajari atau rangsangan yang telah diterima. Sedangkan aplikasi 
diartikan sebagai kemampuan untuk menggunakan materi yang telah dipelajari pada situasi atau kondisi riil (sebenarnya). ${ }^{9}$

Disamping itu, menurut Notoatmodjo sikap dapat juga dipengaruhi oleh faktor lain yaitu lingkungan dan emosi. Dimana, lingkungan dapat menjadikan seseorang memperoleh pengalaman dan pengetahuan baik secara langsung maupun secara tidak langsung sedangkan kemudahan untuk memperoleh suatu informasi dapat membantu mempercepat seseorang untuk memperoleh pengetahuan yang baru. ${ }^{9}$

\section{Sikap Remaja Tentang HIV/AIDS Setelah Dilakukan Intervensi Action Learning}

Setelah dilakukan intervensi action learning sikap remaja tentang HIV/AIDS mengalami peningkatan rata-rata, peningkatan rata-rata sikap tersebut tidak lepas dari upaya peningkatan pembelajaran, salah satu upaya untuk meningkatkan pembelajaran adalah menggunakan metode pembelajaran action laearning.

Action Learning (Aksi Belajar) adalah suatu proses yang melibatkan kelompok kecil yang bekerja pada masalah nyata, mengambil tindakan, dan belajar sebagai individu, sebagai sebuah tim atau kelompok. Aksi Belajar sangat efektif untuk memecahkan masalah yang kompleks yang mungkin muncul dan dapat meningkatkan kolaborasi, kreativitas dan keberanian kelompok untuk memecahkan masalah. ${ }^{10}$

Menurut hasil dari National Training Labolatories di Amerika Serikat menunjukan bahwa dalam kelompok pembelajaran berbasis guru (teacher centered learning) mulai dari ceramah, tugas membaca, presentasi guru dengan audio visual siswa hanya dapat mengingat materi pembelajaran maksimal sebesar $30 \%$. Dalam pembelajaran dengan metode diskusi yang didomonasi oleh guru bukan diskusi kelas dan guru sebagai pemimpin diskusi siswa hanya dapat mengingat sebanyak $50 \%$. Tetapi jika para siswa diberikan kesempatan melakukan sesuatu kegiatan / presentasi didalam kelas mereka dapat mengingat $75 \%$ materi yang diberikan. ${ }^{11}$

Faktor internal yang dapat mempengaruhi kegiatan belajar salah satunya adalah metode pembelajaran yang diberikan kepada siswa. Metode pembelajaran yang monoton seperti ceramah dapat membuat siswa merasa bosan dan minat siswa dalam belajar juga kurang. Dengan adanya metode action laearning ini mengubah pembelajaran yang tadinya monoton menjadi belajar aktif didalam kelas sehingga kualitas pembelajaran menjadi meningkat dan proses pembelajaran mencapai tujuan yang diinginkan.

\section{Pengaruh Action Learning Terhadap Sikap Remaja Tentang HIV/AIDS}

Hasil penelitian menunjukkan bahwa ada pengaruh Action Learning terhadap sikap remaja tentang HIV/AIDS di SMK RISE Kedawung Kabupaten Cirebon.

Action Learning adalah metode pembelajaran yang memusatkan kegiatan siswa daipada aktifitas mengajar guru. ${ }^{(19)}$ Kunci dari pembelajaran action learning itu sendiri terletak pada pertanyaan. Belajar (L) merupakan hasil dari pengetahuan (P) dan pertanyaan (Q) yang selanjutnya dikenal melalui persamaan $\mathrm{L}=\mathrm{P}+\mathrm{Q}$ dimana $\mathrm{P}$ dan $\mathrm{Q}$ sama pentingnya. Kunci dari suatu pembelajaran itu sendiri dimulai dari Q terlebih dahulu. Q dapat menggambarkan suatu masalah yang belum diketahui solusinya atau suatu masalah yang sudah siap untuk dipecahkan. ${ }^{10}$ Salah satu keuntungan yang diperoleh individu melalui pembelajaran action learning adalah action learning mampu meningkatkan pemahaman siswa dalam memahami pelajaran yang diajarkan dan mereka dapat mengingat materi pembelajaranya lebih lama. ${ }^{11}$

Teori tersebut didukung oleh penelitian Astuti (2011) yang berjudul peningkatan partisipasi dan motivasi belajar biologi melalui action learning pada siswa kelas X.6 SMAN 5 Surakarta tahun pelajaran 2009/2010. Hasil penelitian tersebut menunjukkan bahwa siswa dapat meningkatkan partisipasi dan motivasi belajar biologi melalui action learning. 
Action learning terbukti dapat meningkatkan motivasi siswa dalam kegiatan belajar, salah satu kelebihan action learning yaitu siswa akan lebih mudah memahami pelajaran dan meraka akan dapat mengingat pelajaranya lebih lama, sehingga kualitas pembelajaran menjadi meningkat, meningkatnya kualitas pembelajaran dapat mempengaruhi sikap individu yang nantinya sikap tersebut akan mempengaruhi pola pikir individu untuk mengambil keputusan dalam bertindak.

\section{SIMPULAN}

1. Rata-rata (mean) skor sikap remaja tentang HIV/AIDS di SMK RISE Kedawung Kabupaten Cirebon sebelum dilakukan intervensi Action Learning adalah 64,66 (tidak mendukung).

2. Rata-rata (mean) skor sikap remaja tentang HIV/AIDS di SMK RISE Kedawung Kabupaten Cirebon sebelum dilakukan intervensi Action Learning adalah 66,77 (mendukung).

3. Terdapat perbedaan yang bermakna antara kelompok pre-test dengan kelompok post-tes setelah dilakukan intervensi Action Learning, dengan hasil uji statistik Paired T-test didapatkan $P$ Value sebesar 0,000 , sehingga kesimpulanya yaitu ada pengaruh Action Learning terhadap sikap remaja tentang HIV/AIDS di SMK RISE Kedawung Kabupaten Cirebon.

\section{SARAN}

\section{Bagi STIKes Cirebon}

Metode pembelajaran Action Learning dapat dijadikan bahan pembelajaran untuk meningkatkan kopetensi mahasiswa khususnya terkait promosi kesehatan dalam masalah HIV/AIDS dikalangan remaja.

2. Bagi SMK RISE Kedawung Hasil Penelitian ini sebagai masukan kepada sekolah tentang metode Action Learning dalam upaya meningkatkan sikap remaja tentang HIV/AIDS.

3. Bagi Siswa-Siswi SMK RISE Kedawung

Metode action learning dapat menjadi bahan kegiatan pembelajaran sehari-hari sehingga pembelajaran tidak monoton dan jenuh khususnya mengenai materi tentang HIV/AIDS sehingga dapat menumbuhkan kesadaran dan upaya pencegahan deteksi dini tentang HIV/AIDS.

\section{DAFTAR PUSTAKA}

1. Noviana Nana. Kesehatan Reproduksi dan HIV/AIDS.Jakarta:Trans Info Media;2013.

2. Adisasmito Wiku. Sistem Kesehatan. Jakarta:PT Raja Grafindo Persada;2007.

3. Depkes. Laporan triwulan pertama 2011 kasus HIV-AIDS: [diakses tanggal 3 November 2014]. Diunduh dari http/www.depkes.go.id/index.php.

4. WHO. WHO Progres Report [diakses tanggal 3 November 2014]: diunduh dari http://www.who.int/hiv/pub/progress_report2011/en/.

5. Hutapea Ronald. AIDS \& PMS dan perkosaan. Jakarta: PT Rineka Cipta;2011.

6. Mighwar Al Muhamad. Psikologi Remaja. Bandung:Pustaka Setia 2011.

7. Rumini Sri \& Sundari Siti. Perkembangan Anak \& Remaja. Jakarta. PT Rineka Cipta;2011

8. Negara Pandu Mahendra. Pengeruh Action Learning terhadap pengetahuan, dan sikap remaja tentang HIV AIDS dan klinik Voluntary Counseling and Testing (VCT). [Skripsi]. Jember:Universitas Jember:2013.

9. Halima Nur. Belajar Tentang Sikap. [diakses tanggal 26 November 2014. Diunduh dari http://phnconsulting.com/news. 
10. Bawono Hayuning. Action Learning Sebuah Antisipasi Songsong Masa Depan.[diakses tanggal 29 November 2014]. Diunduh dari http://kalipaksi.me/2007/08/20/action-learning-sebuah-antisipasi-songsong-masa depan.

11. Komarudin. Action Learning untuk pembelajaran aktif. [diakses tanggal 22 November 2014]. Diunduh dari http://www.wial.org/action-learning. 